\title{
Pengaruh Ekuitas Merek Terhadap Keputusan Membeli Produk Kosmetik Merek Oriflame
}

\author{
Devi Nilakandi $i^{*}$ \\ ${ }^{1}$ Fakultas Ekonomi, Universitas Mataram, Mataram, Indonesia.
}

\section{Article Info}

Received: 15 Oktober $2020 \quad$ Revised: 25 November 2020

Accepted: 30 November 2020

\begin{abstract}
The purpose of this study was to determine the significance of the effect of brand equity (brand awareness, quality impression, brand association, brand loyalty) of Oriflame cosmetic products on consumer purchases in Mataram City. The population of this study are consumers who make real purchases and consumers who have tried through a demo conducted by personal selling Oriflame cosmetic products. Sampling of 50 consumers really fulfills the requirements for a representative sample. The data collection techniques used were interview techniques and documentation techniques. This analysis is used because in this study there is more than one independent variable. This analysis is used to determine the influence of brand equity (brand awareness, quality impression, brand association, and brand loyalty) on consumer purchase desires (decisions). The results showed that: 1) Brand awareness and perceived quality factors have a significant influence to form an image and influence consumer decisions in purchasing oriflame products; 2) The factors of brand association and consumer loyalty do not have a meaningful influence on purchasing decisions for Oriflame products. This means that brand association and brand loyalty are not the dominant factors that influence consumers to use Oriflame products even though these factors have an influence but the effect is small; and 3) Brand equity has a strong influence on consumer decisions in purchasing Oriflame products. This means that the stimuli attached to the oriflame product create a special attraction that attracts consumers to buy and use oriflame products.
\end{abstract}

Keywords: Brand Equity; Purchase Decision; Cosmetics; Oriflame

Abstrak: Tujuan dari penelitian ini adalah untuk mengetahui signifikansi pengaruh dari ekuitas merek (kesadaran merek, kesan kualitas, asosiasi merek, loyalitas merek) produk kosmetik Oriflame terhadap pembelian konsumen di Kota Mataram. Populasi penelitian ini adalah konsumen yang melakukan pembelian secara nyata dan konsumen yang telah mencoba melalui demo yang dilakukan oleh personal selling produk kosmetik Oriflame. pengambilan sampel sebanyak 50 orang konsumen sangat memenuhi syarat pengambilan sampel yang representatif. Teknik pengumpulan data yang digunakan adalah teknik wawancara dan teknik dokumentasi. Analisa ini digunakan karena dalam penelitian ini terdapat lebih dari satu variable bebas. Analisis ini digunakan untuk mengetahui besarnya pengaruh dari ekuitas merek (kesadaran merek, kesan kualitas, asosiasi merek, dan loyalitas merek) terhadap keinginan (keputusan) pembelian konsumen. Hasil penelitian menunjukkan bahwa: 1) Faktor kesadaran merek dan persepsi kualitas mempunyai pengaruh yang secara signifikan dapat membentuk image dan mempengaruhi keputusan konsumen dalam pembelian produk oriflame; 2) Faktor asosiasi merek dan loyalitas konsumen tidak mempunyai pengaruh yang berartiter hadap keputusan pembelian produk oriflame. Artinya asosiasi merek dan loyalitas merek bukan merupakan faktor dominan yang mempengaruhi konsumen untuk menggunakan produk oriflame walaupun faktor ini mempunyai pengaruh tapi pengaruhnya kecil; dan 3) Ekuitas merek mempunyai pengaruh yang kuat untuk mempengaruhi keputusan konsumen dalam pembelian produk oriflame. Artinya stimulus-stimulus yang melekat pada produk oriflame membuat daya tarik tersendiri yang memikat konsumen untuk membeli dan menggunakan produk oriflame.

Kata Kunci: Ekuitas Merek; Keputusan Membeli; Kosmetik; Oriflame

Citation: Nilakandi, D. (2020). Pengaruh Ekuitas Merek Terhadap Keputusan Membeli Produk Kosmetik Merek Oriflame. ALEXANDRIA (Journal of Economics, Business, E Entrepreneurship. 1(1). 1-7

\section{Introduction}

Dewasa ini persaingan perusahaan untuk memperebutkan konsumen tidak lagi terbatas pada atribut fungsional produk seperti kegunaan suatu produk, melainkan sudah dikaitkan dengan merek yang mampu memberikan citra terhadap suatu produk 
(Putri \& Suasana, 2017). Merek berupa nama atau pembeda antara suatu produk dengan produk yang lain tetapi lebih dari itu merek mampu memberikan gambaran tertentu dalam benak konsumennya (Bakhtiar \& Jayanto, 2015).

Banyak perusahaan yang menghasilkan beberapa jenis produk yang dijual di pasar tentunya harus dibedakan dengan pesaing, oleh karena itu produk tersebut harus diberi tanda, simbol atau desain yang mengidentifikasi dan mendeferensiasi dengan produk lain.

Suksesnya suatu bisnis atau produk tergantung pada kemampuan target pasar dalam membedakan satu produk dengan produk lainnya. Merek adalah alat utama yang digunakan oleh pemasar untuk membedakan produk mereka dari produk pesaingnya (Supriyadi et al., 2017). Merek pada hakekatnya merupakan janji penjual untuk secara konsisten memberi seperangkat atribut, manfaat dan pelayanan (Prajnagaja, 2015). Merek juga sangat bernilai karena mampu mempengaruhi pilihan atau preferensi konsumen (Todar et al., 2020). Merek yang dibangun dengan penciptaan struktur mental yang berhubungan dengan perusahaan, pada ingatan konsumen akan membantu konsumen dalam membantu melakukan keputusan pembelian.

Faktanya, tidak seluruh merek mempunyai kekuatan, tetapi ada juga yang muncul sebagai kelemahan yang menyebabkan produk tidak diserap oleh pasar, karena merek tersebut telah menimbulkan image negatif pada konsumen. Misalnya, dokter praktik yang menyebabkan kecelakaan bagi pasien karena pelayanan yang diberikan dipastikan akan mempunyai nama yang negatif. Konsumen akan berfikir kembali menggunakan jasa dokter bersangkutan.

Manusia dalam menjalani kehidupan tidak lepas dari budaya, di mana dijadikan sebagai pedoman untuk cara hidup termasuk dalam pemenuhan kebutuhan. Salah satu bentuk kebutuhan yang lahir dari konteks budaya adalah kebutuhan kecantikan dan kesehatan. Kebutuhan kecantikan dapat ditemukan pada masyarakat primitive dan modern, yang berbeda adalah cara pemenuhannya.

Produk kosmetik pada prinsipnya untuk memenuhi kebutuhan kecantikan atau keindahan dan kesehatan konsumen. Masyarakat modern sangat menghindari penggunaan kosmetik yang memunyai efek samping, karena bersifat merugikan dalam jangka panjang. Salah satu perusahaan yang menghasilkan produk kosmetik dengan memberikan ciri khas "Menekankan pada gaya, kesederhanaan, teknologi tinggi, dengan pendekatan alami" adalah kosmetik Oriflame.

Oriflame adalah perusahaan kosmetika yang menawarkan produk kosmetik dan perawatan kulit alami berkualitas tinggi melalui jaringan penjual mandiri (independent sales force), yang berbeda dengan sistem retail pada umumnya. Sistem penjualan langsung memungkinkan pelanggan untuk memperoleh nasehat dan inspirasi dari orang yang mereka kenal dan mereka percayai. Pembelian secara langsung dapat diandalkan dan sangat menyenangkan. Menjadi Consultant Oriflame berarti memiliki penghasilan tak terbatas dan peluang karir yang luar biasa, pengembangan pribadi dan rasa saling memiliki dalam komunitas persahabatan global.

Kosmetik Oriflame saat ini adalah perusahaan kosmetik dengan perkembangan tercepat di dunia. Oriflame memiliki kantor penjualan di 61 negara dan merupakan pemimpin pasar di lebih dari 30 negara. Jaringan penjualan yang terdiri dari 2,3 juta Consultants mandiri yang memasarkan rangkaian lengkap perawatan kulit, wewangian dan kosmetik berkualitas tinggi. Di Indonesia sendiri, Oriflame didirikan sejak tahun 1986 dan telah berjaya di Indonesia selama 23 tahun. Oriflame memiliki 13 cabang dan ribuan consultant yang tersebar luas diseluruh Indonesia. Untuk saat ini, Oriflame Indonesia merupakan perusahaan kosmetika dengan sistem penjualan mandiri no.1 di Indonesia. Meskipun berkembang dengan cepat, Oriflame tidak pernah sekalipun melupakan konsep bisnis awalnya Natural Swedish Cosmetics yang dijual dari teman untuk teman.

Konsumen dapat memberikan persepsi atas merek untuk masing-masing produk kosmetik, karena pihak perusahaan telah melakukan identifikasi tertentu atas kebutuhan konsumen yang harus dipenuhi. Misalnya, merek KKI dengan unggulan produk untuk konsumen yang sesuai untuk daerah tropis, kosmetik sophie martin dengan konsep kosmetik wanita gaya masa kini. Merek-merek kosmetik dengan sistem jaringan penjualan mandiri ini telah melakukan pembentukan ciri khas atas produk yang dipasarkan pada konsumen.

Pencitraan atas merek kosmetik Oriflame telah dilakukan, selanjutnya konsumen yang memberikan persepsi atas merek yang bersangkutan. Harapan perusahaan adalah terbentuknya brand image yang positif dari konsumen. Kosmetik merek Oriflame menghasilkan produk yang sangat beragam sesuai dengan kompleksitas kebutuhan kecantikan konsumen, karena pada prinsipnya seluruh tubuh konsumen membutuhkan alat pemuas untuk menjadi cantik, indah dan sehat.

Kosmetik merupakan produk khusus, dimana konsumen dalam melakukan pembelian menyembunyikan motivasi pembeliannya. Bentuk kebutuhan tersebut adalah kebutuhan kecantikan, pemenuhan kelas sosialnya dan berbagai kebutuhan 
tersembunyi lainnya. Produk kosmetik melalui kekuatan merek akan terhindar dari pengaruh harga yang rendah dalam membentuk pembeliannya. Kosmetik Oriflame menerapkan strategi menghasilkan banyak ragam produk kosmetik dengan nama produk yang berbeda-beda, tetapi dengan merek yang sama yaitu Oriflame. Misalnya untuk produk lipstik warnawarni, matt lipstick (tidak mengkilap), lipmoist (kaya pelembab) dan lipliner pencil. Produk tersebut hanya untuk satu kebutuhan yaitu, kecantikan dan kesehatan bibir, belum lagi kebutuhan kecantikan dan kesehatan rambut, wajah, kulit dan bentuk lainnya di masingmasing mempunyai kedalaman produk yang tinggi.

Kosmetik Oriflame sebagai produk yang relatif baru memasuki pasar (khusus di Kota Mataram) mengharapkan agar konsumen mempunyai keinginan mencoba, selanjutnya beralih menggunakan merek bersangkutan dengan loyal. Hal ini dilihat dari kegiatan pemasaran yang dilakukan dengan lebih banyak menggunakan sistem "demo" (pemberian contoh), sistem pengenalan produk dengan menggunakan katalog-katalog pada konsumen potensial. Untuk sistem "demo" yang juga dilakukan untuk memasarkan produknya dapat dilakukan pada kelompok arisan para ibu, mall atau tempat lain dengan kuantitas konsumen potensial yang tinggi.

Adapun perbedaan kosmetik Oriflame dengan kosmetik lain yang mendasari konsumen di Kota Mataram memilih produk Oriflame berupa kebaikan dari produk kosmetik yang dimiliki Oriflame, seperti : produk-produk Oriflame tidak diuji cobakan pada hewan, tetapi pada sukarelawan dengan menjamin kemananan, kecocokan serta efektifitas termasuk bagi kulit yang sensitif, Oriflame menekankan pada penggunaan bahan-bahan dan sari pati alami, produkproduk Oriflame dijamin murni dan berkualitas tinggi. Dikembangkan di pabrik yang berteknologi tinggi di bawah pengawasan mutu dan lingkungan yang ketat, Oriflame menggunakan aerosol yang akrab dan aman terhadap ozon, kemasan produk Oriflame dapat didaur ulang dan aman terhadap lingkungan. Beberapa kebaikan inilah yang menjadi nilai lebih kosmetik Oriflame di mata para konsumen dan pelanggan, sehingga para konsumen lebih memilih dan mempercayai kosmetik Oriflame dan pelanggan tidak perlu khawatir dalam menggunakan kosmetik Oriflame yang terpercaya.

Kosmetik Oriflame sudah cukup dikenal oleh masyarakat di Kota Mataram Hal ini dibuktikan dengan sebagian besar remaja maupun para ibu-ibu sudah mengenal merek Oriflame dengan baik, bahkan diantara mereka menjadi pelanggan tetap Oriflame. Banyak para remaja yang menggemari kosmetik Oriflame, karena kosmetik Oriflame memiliki produk yang beraneka ragam dan sesuai dengan kebutuhan konsumennya, disamping itu kosmetik Oriflame memiliki kandungan kosmetik yang ringan dan tidak menimbulkan efek samping yang membuat konsumen nyaman dalam mengkonsumsi kosmetik Oriflame, selain itu dari segi harga kosmetik Oriflame dapat menjangkau konsumen kelas menengah ke bawah. Dengan melihat fenomena persaingan merek kosmetik yang ada di Kota Mataram, Oriflame tetap bertahan menjadi pilihan para konsumen, fenomena ini menunjukkan bahwa kosmetik Oriflame dapat mempertahankan eksistensi daripada mereknya. Hal inilah yang mendasari peneliti untuk memilih Oriflame sebagai objek penelitian.

Produk kosmetik Oriflame menunjukkan dominasinya dalam menguasai market share kosmetik khususnya di Kota Mataram. Dalam hal ini tergambar betapa aroma persaingan antara produk kosmetik dalam memperebutkan posisi market leader sangat ketat. Oriflame produk kosmetik produksi PT. Oriflame Cosmetics Indonesia sebagai market leader dengan perolehan market share sebanyak 47,02 \%. Sedangkan kosmetik merek KKI produksi PT. KK Indonesia dengan perolehan market share $31,57 \%$. Shopie Martin produksi PT. Sophie Martin perolehan market share 20,23\%. Dari data tersebut terlihat market share teratas ditempati oleh kosmetik Oriflame, yang akhirnya mengkokohkan sebagai market leader dalam persaingan kosmetik khususnya di kota Mataram.

Pemasaran kosmetik Oriflame dilakukan dengan distributor khusus, yaitu melalui distributor PT. Oriflame Cosmetics Indonesia. Berbeda dengan produk kosmetik lainnya dengan menggunakan distributor umum, dalam arti produknya dapat ditemukan sampai di toko-toko kecil. Produk kosmetik Oriflame dijual melalui counter khusus yang ada di Kota Mataram melalui jasa Consultant Oriflame dengan tujuan untuk membentuk image konsumen bahwa produk tersebut adalah merek khusus. Adapun perbedaan penjualan Oriflame dengan kosmetik yang lain adalah dengan memperkenalkan produknya melalui katalog-katalog, dimana dalam katalog ini segala macam produk perawatan kecantikan memiliki daftar tersendiri yang langsung disertai dengan harga dari produk tersebut.

Strategi di atas sebagai upaya untuk membentuk kekuatan atas merek Oriflame, sehingga dengan mengetahui merek dari produk tersebut telah dapat dilakukan identifikasi khas dari produk Oriflame, menumbuhkan persepsi kualitas, menumbuhkan alasan pembelian dan kepuasan penggunaan..

Dengan melihat kondisi di atas terbukti bahwa kosmetik Oriflame merupakan salah satu pilihan bagi para pengguna (konsumen) kosmetik, baik konsumen yang sudah menjadi pelanggan tetap maupun para konsumen yang baru mencoba kosmetik Oriflame. Hal 
ini mengakibatkan jumlah pelanggan pembelian kosmetik Oriflame terus meningkat sehingga bisa mengakibatkan dampak yang positif terhadap merek Oriflame. Semakin banyaknya pelanggan apabila tidak diimbangi dengan kualitas produk yang tinggi akan membuat kecewa para pelanggan atas merek yang bersangkutan. Dengan adanya kondisi tersebut kosmetik Oriflame perlu meningkatkan mutu dari merek dan produk kosmetik Oriflame untuk semakin mengoptimalkan kepuasan para pelanggan kosmetiknya dan meningkatkan pembelian terhadap kosmetik Oriflame.

\section{Method}

Jenis penelitian yang dilakukan termasuk dalam penelitian asosiatif kausal adalah hubungan sebab akibat, penelitian ini bertujuan untuk mengetahui pengaruh ekuitas merek (kesadaran merek, kesan kualitas, asosiasi merek, loyalitas merek) terhadap keputusan membeli kometik Oriflame di Kota Mataram.

Populasi penelitian ini adalah konsumen yang melakukan pembelian secara nyata dan konsumen yang telah mencoba melalui demo yang dilakukan oleh personal selling produk kosmetik Oriflame. Adanya jumlah populasi yang cukup besar maka metode pengumpulan data yang digunakan adalah metode sample survey. Metode sample survey yaitu suatu prosedur yang mana hanya sebagian dari populasi saja yang diambil dan digunakan untuk menentukan sifat serta ciri yang menggambarkan populasi keseluruhan untuk memperoleh data yang representatif.

Jumlah sampel yang diambil lebih disesuaikan dengan kemampuan peneliti dan setidaknya dapat mewakili populasi yang ada di Kota Mataram. Untuk itu, jumlah sampel yang diambil sebanyak 50 responden, junlah ini tergolong data besar. Hal ini didukung dengan pernyataan Djarwanto (1995) bahwa sampel sebanyak 30 termasuk data besar, dengan demikian pengambilan sampel sebanyak 50 orang konsumen sangat memenuhi syarat pengambilan sampel yang representatif.

Mengingat identitas populasi yang belum diketahui secara pasti dan setiap saat mengalami perubahan dengan munculnya konsumen baru atau kemungkinan konsumen yang pindah pada merek lain, maka teknik penentuan responden secara nonprobability sampling yaitu menggunakan purposive sampling terkait dengan identitas populasi.

Teknik pengumpulan data yang digunakan adalah teknik wawancara dan teknik dokumentasi. Dalam rangka memberikan kemudahan melakukan wawancara atau pengumpulan data dengan teknik wawancara, maka diperlukan panduan berupa kuisioner yang berupa daftar pertanyaan yang disusun peneliti, berisikan berbagai indikator untuk keputusan pembelian, kesadaran merek, kesan kualitas, asosiasi merek dan loyalitas merek.

Jenis data yang digunakan dalam penelitian ini adalah kualitatif data kualitatif yang merupakan data yang berupa keterangan-keterangan atau data yang tidak dapat dinyatakan dalam bilangan secara langsung, dan data kuantitatif yang merupakan data yang dapat diukur secara langsung, dalam penelitian ini berupa nilai yang dikorbankan oleh konsumen untuk memenuhi kebutuhan kosmetik dan nilai pembelian untuk produk kosmetik Oriflame. Sumber data utama dalam penelitian ini adalah responden, sedangkan data pelengkapnya berupa brosur atau buku-buku panduan untuk produk kosmetik Oriflame.

Analisa ini digunakan karena dalam penelitian ini terdapat lebih dari satu variable bebas. Analisis ini digunakan untuk mengetahui besarnya pengaruh dari ekuitas merek (kesadaran merek, kesan kualitas, asosiasi merek, dan loyalitas merek) terhadap keinginan (keputusan) pembelian konsumen. Rumus regresi linear berganda menurut Sugiyono (1999).

$$
Y=a+b_{1} X_{1}+b_{2} X_{2}+b_{3} X_{3}+b_{4} X_{4}+e i
$$

Dimana :

$$
\begin{array}{ll}
\mathrm{Y} & =\text { Ekuitas Merek } \\
\mathrm{A} & =\text { Konstanta Regresi } \\
\mathrm{b} 1 & =\text { Koefisien Regresi } \\
\mathrm{X}_{1} & =\text { Persepsi Kualitas } \\
\mathrm{X}_{2} & =\text { Loyalitas Merek } \\
\mathrm{X}_{3} & =\text { Kesadaran Merek } \\
\mathrm{X}_{4} & =\text { Asosiasi Merek } \\
\mathrm{ei} & =\text { Kesalahan pengganggu (Error of estimate) }
\end{array}
$$

\section{Result and Discussion}

Berdasarkan hasil analisis SPSS diperoleh nilainilai pada Tabel 1. 
Tabel 1. Hasil Analisis Perhitungan Regressi Untuk Setiap Variabel

\begin{tabular}{|c|c|c|c|c|c|c|c|c|}
\hline \multirow[t]{3}{*}{ Model } & \multirow{2}{*}{\multicolumn{2}{|c|}{$\begin{array}{l}\text { Unstandardized } \\
\text { Coefficients }\end{array}$}} & \multirow{3}{*}{$\begin{array}{l}\text { Standardizec } \\
\text { Coefficients } \\
\text { Beta }\end{array}$} & \multirow{3}{*}{$\mathrm{t}$} & \multirow{3}{*}{ Sig. } & \multicolumn{3}{|c|}{ Correlations } \\
\hline & & & & & & & & \\
\hline & $\bar{B}$ & Std. Error & & & & Zero order & Partial & Part \\
\hline (Constant) & -7.441 & 4.461 & & -1.668 & 0.102 & & & \\
\hline $\mathrm{x} 1$ & 0.947 & 0.346 & 0.318 & 2.737 & 0.009 & 0.578 & 0.378 & 0.269 \\
\hline$x 2$ & 0.534 & 0.242 & 0.279 & 2.209 & 0.032 & 0.533 & 0.313 & 0.217 \\
\hline$x 3$ & 0.554 & 0.337 & 0.235 & 1.644 & 0.107 & 0.630 & 0.238 & 0.162 \\
\hline$x 4$ & 0.329 & 0.207 & 0.183 & 1.589 & 0.119 & 0.461 & 0.230 & 0.156 \\
\hline
\end{tabular}

Berdasarkan hasil analisis SPSS untuk model regressi linier berganda, maka dapat dibentuk persamaan regressi sebagai berikut :

$\mathrm{Y}=-7,441+0,947 \times 1+0,534 \times 2+0,554 \times 3+0,329 \times 4+\mathrm{ei}$

Dari persamaan di atas maka perlu dilakukan first order test untuk melihat tingkat signifikansi setiap variabel dengan menggunakan uji t sebagai berikut:

\section{a. Persepsi Kualitas}

Hasil analisis regresi untuk variabel persepsi kualitas produk oriflame menunjukkan nilai koefisien regressi sebesar 0,947 dengan $\mathrm{t}$ sebesar 2,737 dengan tingkat probabilitas sebesar 0,009 maka dengan demikian persepsi kualitas mempunyai pengaruh yang signifikan pada tingkat kepercayaan 5\% dengan keputusan konsumen dalam menggunakan produkproduk oriflame.

Nilai korelasi sebesar 0,578 mengindikasikan bahwa secara parsial persepsi kualitas mempunyai tingkat hubungan yang cukup kuat, terhadap keputusan konsumen dalam penggunaan produk kosmetik oriflame. Sedangkan nilai determinasi parsial sebesar 0,378 mengindikasikan bahwa persepsi kualitas merupakan faktor yang secara parsial mempunyai kontribusi sebesar 37,8\% terhadap keputusan penggunaan produk kosmetik oriflame sedangkan sisanya sebesar 62,2 dipengaruhi oleh faktor lain.

\section{b. Kesadaran Merek}

Hasil analisis regresi untuk variabel kesadaran merek produk oriflame menunjukkan nilai koefisien regressi sebesar 0,534 dengan $t$ sebesar 2,209 dengan tingkat probabilitas sebesar 0,032 dengan demikian maka kesadaran merek mempunyai pengaruh secara signifikan pada tingkat kepercayaan 5\% dengan keputusan konsumen dalam menggunakan produkproduk oriflame.

Nilai korelasi sebesar 0,533 mengindikasikan bahwa secara parsial persepsi kualitas mempunyai tingkat hubungan yang cukup kuat terhadap keputusan konsumen dalam penggunaan produk kosmetik oriflame. Sedangkan nilai determinasi parsial sebesar 0,313 mengindikasikan bahwa persepsi kualitas merupakan faktor yang secara parsial mempunyai kontribusi sebesar 31,3\% terhadap keputusan penggunaan produk kosmetik oriflame sedangkan sisanya sebesar 68,7 dipengaruhi oleh faktor lain diluar model.

\section{c. Asosiasi merek}

Hasil analisis regresi untuk variabel asosiasi merek produk oriflame menunjukkan nilai koefisien regressi sebesar 0,554 dengan $t$ sebesar 1,644 dengan tingkat probabilitas sebesar 0,107 dengan demikian asosiasi merek secara parsial tidak mempunyai pengaruh secara signifikan pada tingkat kepercayaan $5 \%$ ataupun $10 \%$ dengan keputusan konsumen dalam menggunakan produk-produk oriflame. Karena secara parsial asosiasi merek tidak mempunyai hubungan yang signifikan maka pembahasan tidak perlu dilanjutkan untuk nilai corelasi dan determinasinya.

\section{d. Loyalitas Konsumen}

Hasil analisis regresi untuk variabel loyalitas konsumen terhadap produk oriflame menunjukkan nilai koefisien regressi sebesar 0,329 dengan $t$ sebesar 1,589 dengan tingkat probabilitas sebesar 0,119 dengan demikian tidak mempunyai pengaruh secara signifikan pada tingkat kepercayaan 5\% ataupun 10\% dengan keputusan konsumen dalam menggunakan produkproduk oriflame. Karena tidak adanya pengaruh yang signifikan maka dalam penelitian ini loyalitas konsumen tidak dijelaskan lebih lanjut.

\section{Pengaruh Ekuitas Merek Terhadap Keputusan Penggunaan Produk Oriflame}

Berdasarkan persamaan regressi yang dibentuk yaitu $Y=-7,441+0,947 \times 1+0,534 \times 2+0,554 \times 3+$ $0,329 \times 4+e i$, model ini menunjukkan bahwa jika tanpa ekuitas merek atau ekuitas merek bernilai nol, maka nilai keputusan konsumen akan berkurang sejumlah proporsi -7,441. Sedangkan nilai 0,947 mengidikasikan bahwa peningkatan nilai 1 tingkat pada persepsi kualitas meningkatkan nilai keputusan pembelian sebesar 0,947 dengan asumsi bahwa faktor lain konstan. Nilai 0,534 mengidikasikan bahwa peningkatan nilai 1 tingkat pada kesadaran merek meningkatkan nilai keputusan pembelian sebesar 0,534 dengan asumsi bahwa faktor lain konstan. Nilai 0,554 mengidikasikan bahwa peningkatan nilai 1 tingkat pada asosiasi merek meningkatkan nilai keputusan pembelian sebesar 0,554 dengan asumsi bahwa faktor lain konstan. Sedangkan nilai 0,329 
mengindikasikan bahwa mengidikasikan bahwa peningkatan nilai 1 tingkat pada loyalitas konsumen meningkatkan nilai keputusan pembelian sebesar 0,329 dengan asumsi bahwa faktor lain konstan.

Secara simultan diketahui bahwa setiap elemen ekuitas merek yaitu persepsi kualitas, kesadaran merek, asosiasi merek dan loyalitas konsumen mempunyai pengaruh yang signifikan berdasarkan uji $\mathrm{F}$ pada analisis regressi yang menghasilkan nilai sebesar 14,612 yang signifikan pada tingkat kepercayaan $5 \%$ dengan probabilitas 0,000. Artinya bahwa nilai $\mathrm{F}$ hitung jauh lebih besar daripada nilai $\mathrm{F}$ tabel. Dengan demikian semakin besar beda antara nila $\mathrm{F}$ hitung dan $\mathrm{F}$ tabel maka nilai probabilitas akan mendekati 0,000 yang mengindikasikan bahwa secara serentak atau simultan ekuitas merek merupakan faktor yang mempengaruhi keputusan konsumen dalam pembelian produk oriflame.

Nilai koefisien determinasi sebesar 0,565 menunjukkan bahwa secara bersama-sama faktor ekuitas merek yaitu persepsi kualitas, kesadaran merek, asosiasi merek, dan loyalitas konsumen mempunyai kontribusi terhadap keputusan konsumen dalam pembelian dan penggunaan produk kosmetik oriflame sebesar $56,5 \%$ sedangkan sisanya $43,5 \%$ dipengaruhi oleh faktor lain diluar model. Analisis regressi menghasilkan nilai koefisien korelasi sebesar 0,752 dengan demikian pengaruh ekuitas merek tergolong kuat.

Hasil analisis regresi baik secara parsial maupun simultan menunjukkan bahwa ekuitas merek mempunyai peranan yang kuat dalam pembentukan persepsi konsumen untuk membeli dan menggunakan produk kosmetik oriflame. Dari beberapa item analisis yang ada pada ekuitas merek yaitu faktor kesadarann merek, persepsi kualitas, asosiasi merek dan loyalitas konsumen ternyata secara serentak berdasarkan uji $F$ menyatakan keempat elemen ekuitas merek tersebut mempunyai pengaruh yang signifikan terhadap perubahan persepsi dan keputusan konsumen dalam pembelian dan penggunaan produk kosmetik oriflame. Tetapi secara terpisah ternyata hanya ada dua faktor yang memiliki pengaruh yang signifikan yaitu factor persepsi kualitas dan kesadaran merek sedangkan asosiasi merek dan loyalitas konsumen secara parsial tidak mempunyai pengaruh yang nyata. Tingginya persepsi kualitas, meningkatkan kesadaran yang baik terhadap merek tersebut. Kemampuan suatu merek untuk meningkatkan dan menjaga kualitas produknya dan memahami keinginan konsumennya merupakan suatu faktor yang sangat kuat pengaruhnya terhadap keputusan konsumen dan meningkatkan loyalitas konsumen terhadap suatu produk.
Setiap konsumen pasti menginginkan produk yang digunakan mempunyai kualitas yang baik. Tidak dapat dibantah lagin setiap konsumen mengeluarkan sejumlah uang bahkan dengan jumlah yang sangat besar dengan harapan apa yang diperolehnya merupakan barang yang berkualitas. Kualitas merupakan salah satu kekayaan merek yang dominan dalam penentuan pembelian. Bahkan banyak konsumen tidak mempertimbangkan harga yang penting barang yang dikonsumsi merupakan produk dengan kualitas yang baik dan terjamin.

Produk oriflame membangun persepsi konsumennya dengan begitu baik, hal ini terlihat dari jawaban responden yang rata-rata setuju bahwa oriflame merupakan produk yang bermanfaat dan berkhasiat untuk menjaga kecantikan mereka, aman terhadap kulit dan kesehatan, serta ramah lingkungan. Dengan menggunakan oriflame konsumen merasakan manfaat sesuai dengan yang dijanjikan oleh produsennya melalui promosi atau presentasi. Bahkan pemberian konseling kepada pelanggan atau member oriflame merupakan suatu nilai plus bagi konsumen.

Pengetahuan terhadap produk dan bagaimana cara penggunaan serta kiat-kiat tertentu untuk perawatan wajah dan kulit serta anggota tubuh lainnya dalam konseling oriflame memberikan persepsi yang mampu mengangkat keyakinan dan mempengaruhi keputusan konsumen dalam pembelian dan penggunaan produk oriflamme. Karena dengan pengetahuan yang semakin baik konsumen akan merasa yakin akan produk yang digunakannya dan tahu bagaimana mengoptimalkan penggunaan produk. Selain persepsi kualitas, ekuitas merek yang melekat pada produk-produk oriflame yang dominan adalah kesadaran terhadap merek produk oriflame. Kesadaran merupakan faktor yang bisa membuat perubahan terhadap perilaku konsumen. Kesadaran yang baik akan meningkatkan rasa tertarik konsumen sehingga mau membeli suatu produk, kesadaran selain meningkatkan rasa tertarik juga meningkatkan image positif terhadap produk. Sebagaimana yang dinyatakan oleh banyak konsumen bahwa produk oriflame merupakan produk ekslusif dan merupakan symbol kecantikan wanita modern. Jika oriflame membentuk kesadaran seperti hal tersebut, maka konsumen tentunya merasa senang untuk menggunakan. Karena menurut mereka jika menggunakan produk oriflame berarti menggunakan produk ekslusif dan termasuk wanita modern.

Kesadaran merupakan kemampuan seorang konsumen untuk menangkap dan mengerti serta mengenali suatu produk berdasarkan ciri khas dan kelebihan yang dimiliki oleh produk tersebut. 
Kesadaran yang tinggi akan terbentuk dari pembentukan kesan yang baik dalam diri konsumen. Kesan merupakan bentuk pencitraan suatu produk atau merek ataupun hal lainnya pada seorang konsumen. Pencitraan yang baik akan mengembangkan kesadaran yang baik. Oriflame mampu membentuk dan membangun citra yang baik terhadap konsumen-konsumennya.

Hal ini sangat relevan dengan cara pemasaran produk oriflame yang merupakan produk multi level marketing yang mempunyai pasar cukup kuat. Produk ini dipasarkan dengan cara distribusi orang ke orang dan jenis promosi yang langsung menyentuh yaitu melalui personal ke personal atau untuk teman ke teman. Hal ini jelas mengembangkan citra produk tersebut secara lebih mendalam dan membangkitkan suatu image yang lebih kuat dalam diri konsumennya.

Pemasaran produk yang bersifat personal menyebabkan kekuatan merek ini terbangun secara personal pula, artinya konsumen mengetahui tentang produk ini langsung melalui pemasaran resmi pada agen-agen dari produk oriflame yang biasanya merupakan orang-orang yang dikenal baik oleh konsumen. Sehingga pencitraan terhadap merek akan menjadi lebih kuat.

Asosiasi merek pada penelitian ini kurang memberikan kontribusi nyata karena konsumen tidak mampu membandingkan karakteristik eksternal produk oriflame dengan produk lain yang sejenis, hal ini menyebabkan konsumen tidak melakukan perbandingan sehingga asosiasi merek merupakan faktor yang kurang dominan. Begitu juga dengan loyalitas konsumen, pada penelitian ini faktor loyalitas tidak memberikan pengaruh atau kontribusi yang berarti. Hal ini disebabkan karena umumnya konsumen akan mencoba produk lain, selain karena faktor kepuasan faktor lain yang lebih bersifat alami adalah naluri setiap individu untuk mencoba hal baru. Karenanya kewajiban setiap produsen untuk tetap menjaga kualitas produk dan memberikan inovasi untuk kemajuan dan peningkatan produknya

\section{Kesimpulan}

Keputusan konsumen akan dipengaruhi oleh berbagai faktor baik faktor yang datang dari produk itu sendiri maupun faktor yang datang dari individu konsumen. Dengan demikian dapat disimpulkan bahwa: 1) Faktor kesadaran merek dan persepsi kualitas mempunyai pengaruh yang secara signifikan dapat membentuk image dan mempengaruhi keputusan konsumen dalam pembelian produk oriflame; 2) Faktor asosiasi merek dan loyalitas konsumen tidak mempunyai pengaruh yang berartiter hadap keputusan pembelian produk oriflame. Artinya asosiasi merek dan loyalitas merek bukan merupakan faktor dominan yang mempengaruhi konsumen untuk menggunakan produk oriflame walaupun faktor ini mempunyai pengaruh tapi pengaruhnya kecil; dan 3) Ekuitas merek mempunyai pengaruh yang kuat untuk mempengaruhi keputusan konsumen dalam pembelian produk oriflame. Artinya stimulus-stimulus yang melekat pada produk oriflame membuat daya tarik tersendiri yang memikat konsumen untuk membeli dan menggunakan produk oriflame.

\section{References}

Bakhtiar, A., \& Jayanto, D. (2015). Analisis ElemenElemen Brand Equity Pada Produk Kartu Seluler Prabayar Simpati, Im3, Dan Xl Di Kalangan Mahasiswa S1 Universitas Diponegoro. J@Ti Undip: Jurnal Teknik Industri, 10(3), 155-162. https://doi.org/10.12777/jati.10.3.155-162

Prajnagaja, S. D. (2015). Dampak Brand Equity Pada Keputusan Pembelian Melalui Brand Preference Konsumen Pada Produk Televisi Merek Sony Di Kota Pekanbaru. JOMFekom, 2(1), 843857.

https://media.neliti.com/media/publications/1 2 5589-ID-analisis-dampak-pemekaran-daerahditinja.pdf

Putri, V. D. A., \& Suasana, I. G. A. K. G. (2017). Pengaruh Elemen Ekuitas Merek Terhadap Keputusan Pembelian Di Gerai Starbucks Coffee (Studi Pada Konsumen Domestik Starbucks Coffee di Wilayah Bali). EJurnal Manajemen Universitas Udayana, 7(1), 470. https://doi.org/10.24843/ejmunud.2018.v7.i01.p1 8

Supriyadi, S., Wiyani, W., \& Nugraha, G. I. K. (2017). Pengaruh Kualitas Produk Dan Brand Image Terhadap Keputusan Pembelian. Jurnal Bisnis Dan Manajemen, 4(1). https://doi.org/10.26905/jbm.v4i1.1714

Todar, M. P., Tumbel, A., Jorie, R. J., Sam, U., \& Manado, R. (2020). Pengaruh Persepsi Merek Dan Kualitas Produk Terhadap Keputusan Pembelian Air Minum Dalam Kemasan (Amdk) Galon Merek Aqua the Effect of Brand Perception and Product Quality Toward Purchase Decision Gallon Bottle Drinking Water Aqua Brand. Jurnal EMBA, 8(3) 